\title{
PENGARUH PENERAPAN MODEL PEMBELAJARAN VALUE CLARIFICATION TECHNIQUE TERHADAP CIVIC DISPOSITION SISWA KELAS XI SMA NEGERI 1 TERAS BOYOLALI TAHUN AJARAN 2016/2017
}

Oleh :

\author{
Nur Aini \\ Program Studi Pendidikan Pancasila dan Kewarganegaraan FKIP UNS \\ e-mail: nuraini160794@gmail.com \\ Winarno \\ Universitas Sebelas Maret Surakarta \\ e-mail: winarnonarmoatmojo@staff.uns.ac.id \\ M. Hendri Nuryadi \\ Universitas Sebelas Maret Surakarta \\ e-mail: muhammadhendrinuryadi@staff.uns.ac.id
}

\begin{abstract}
The objective of research was to find out whether or not there is an effect of value clarification technique learning model application on civic disposition in the 11th graders of SMA Negeri 1 Teras Boyolali in the school year of 2016/2017. This study was an experimental quantitative research. The research design was true experimental design with posttest only control design model. The population of research was the 11th graders of SMA Negeri 1 Teras Boyolali in the school year of 2016/2017. The sampling technique used was cluster random sampling. The sample of research consisted of 68 students: 34 in experimental and 34 in control groups. Data collection in this research was carried out using observation and questionnaire. Data validation for the students' civic disposition questionnaire in basic competency of conceiving various effects and threats against the state in maintaining Bhinneka Tunggal Ika was carried out using validity and reliability test. To find out whether or not the items of question were valid, Pearson's product moment correlational formula was used. Meanwhile, the reliability used in this research was Alpha Cronbach. Technique of analyzing data used was a two-independent sample t test.

Considering the research an average score of 86,03 experimental class is higher than he average score of 80,76 control class. Then the hypothesis testing using a two independent sample $t$ test with $t$ statistic > t tabel 13,560 > 1,997 at significance level of 5\% means that there are difference of civic disposition between the students in experiment and those in control classes. So that from the
\end{abstract}


result it could be found that there was an effect of value clarification technique learning model on the students' civic disposition in basic competency of conceiving various effects and threats against the state in maintaining Bhinneka Tunggal Ika in the 11th graders of SMA Negeri 1 Teras Boyolali in the School Year of 2016/2017.

Keywords: Value Clarification Technique, Civic Disposition

\section{PENDAHULUAN}

Indonesia adalah suatu negara multikultural yang memiliki keragaman budaya, ras, suku, agama dan golongan yang kesemuanya merupakan kekayaan tak ternilai yang dimiliki bangsa Indonesia. Pluralitas dan heterogenitas yang tercermin pada masyarakat Indonesia diikat dalam prinsip persatuan dan kesatuan bangsa yang kita kenal dengan semboyan "Bhinneka Tunggal Ika", yang mengandung makna meskipun Indonesia berbhinneka, tetapi terintegrasi dalam kesatuan.

Keadaan Indonesia yang multikultur akan sangat tergantung pada bagaimana masyarakat Indonesia membawanya. Keadaan ini bisa dibawa pada jalur yang menjadikannya suatu kekayaan atau kekuatan bangsa, namun bisa pula dibawa pada jalur yang akan menjadi pemecah belah dan penyulut konflik di masyarakat. Kemungkinan munculnya benih-benih percecokan pada masyarakat multikultur sangat rawan terjadi jika masyarakat multikultur menyikapi perbedaan sebagai suatu pemisah.

Benih-benih konflik bernuansa SARA nampaknya juga terjadi di lingkungan sekolah, dimana ada kecenderungan siswa untuk menolak pemimpin yang berbeda agama. Hasil penelitian yang dilakukan oleh Pusat Penelitian Kebijakan Pendidikan dan Kebudayaan (Puslitjakdikbud), Badan Penelitian dan Pengembangan, Kementerian Pendidikan dan Kebudayaan (Kemendikbud) di 2 SMA negeri dan 2 SMA swasta di Kota Salatiga dan Singkawang menunjukkan sekitar $25 \%$ siswa lebih nyaman berteman dengan siswa lain yang seetnis dan seagama, sekitar $20 \%$ siswa lebih cenderung memilih ketua OSIS yang seagama, dan lebih dari $40 \%$ siswa lebih setuju memilih pemimpin masyarakat yang seagama dan seetnis (Artikel Berita Kompas, 2017: 13).

Masyarakat Indonesia yang berbhinneka dapat dibangun dengan adanya manusia yang cerdas dan bermoral. Pemahaman tentang nilainilai kebhinnekaan menjadi keniscayaan yang harus dimiliki oleh masyarakat Indonesia. Sebab di atas nilai-nilai itulah kehidupan masyarakat yang beraneka ragam dapat hidup berdampingan secara damai. Upaya membangun pemahaman tentang nilainilai kebhinnekaan salah satunya dapat melalui pendidikan. 
Pendidikan Pancasila dan Kewarganegaraan mempunyai peranan penting dalam membentuk dan mewujudkan siswa menjadi warga negara yang cerdas dan baik (smart and good citizenship). Untuk mencapai tujuan tersebut diperlukan komponen utama Pendidikan Pancasila dan Kewarganegaraan yaitu pengetahuan kewarganegaraan (civic knowledge), keterampilan kewarganegaraan (civic skills), dan sikap kewarganegaraan (civic disposition).

Civic disposition menjadi komponen yang penting karena menjadi muara bagi kedua komponen lainnya. Sebagaimana kita ketahui bahwa sikap seseorang ditentukan oleh nilai-nilai yang dianutnya. Salah satu nilai yang diharapkan melandasi civic disposition siswa dalam mata pelajaran Pendidikan Pancasila dan Kewarganegaraan adalah nilai kebhinnekaan.

Berdasarkan observasi yang dilakukan di kelas XI SMA Negeri 1 Teras Boyolali ada kecenderungan siswa mengejek temannya berdasarkan fisik mereka yang gemuk, mata yang sipit, atau memiliki kulit yang gelap dibandingkan teman yang lainnya. Selain itu, siswa lebih memilih dipimpin oleh ketua kelas laki-laki dibandingkan perempuan. Siswa cenderung menganggap perempuan lebih sesuai menempati posisi sebagai sekretaris maupun bendahara kelas. Kemudian perbedaan pandangan adakalanya memunculkan kelompokkelompok di kalangan siswa.
Guru Pendidikan Pancasila dan Kewarganegaraan dituntut menguasai dan mampu menggunakan pendekatan, strategi, metode, teknik, dan model pembelajaran yang mampu menunjang pembelajaran Pendidikan Pancasila dan Kewarganegaraan sebagai pendidikan nilai. Teknik mengklarifikasi nilai (value clarification technique) atau sering disingkat "VCT dapat diartikan sebagai teknik pengajaran untuk membantu siswa dalam mencari dan menentukan suatu nilai yang dianggap baik dalam menghadapi suatu persoalan melalui proses menganalisis nilai yang sudah ada dan tertanam dalam diri siswa" (Wina Sanjaya, 2014: 283).

Tujuan penelitian adalah mengetahui ada tidaknya pengaruh penerapan model pembelajaran value clarification technique terhadap civic disposition siswa pada kompetensi dasar menghayati berbagai dampak dan bentuk ancaman terhadap negara dalam mempertahankan Bhinneka Tunggal Ika. Adapun hasil dari penelitian ini diharapkan dapat memberikan manfaat untuk beberapa kalangan. Secara teoritis hasil penelitian ini diharapkan dapat menguatkan teori yang sudah ada terkait pengaruh model pembelajaran value clarification technique terhadap civic disposition siswa serta memberikan kontribusi bagi perkembangan ilmu pengetahuan dan menjadi bahan pertimbangan dalam penelitian selanjutnya yang relevan. Manfaat secara praktis adalah untuk menambah wawasan guru terkait model pembelajaran yang dapat digunakan 
untuk meningkatkan civic disposition siswa, sehingga siswa dapat memahami dan memperoleh pengetahuan tentang nilai-nilai yang didapat di sekolah, sehingga dapat diimplementasikan dalam kehidupan sehari-hari.

\section{METODE PENELITIAN}

Penelitian ini dilaksanakan di SMA Negeri 1 Teras Boyolali kelas XI semester dua tahun ajaran 2016/2017. Rancangan/Desain Penelitian yang digunakan dalam penelitian ini adalah True Experimental Design yaitu bentuk Posttest Only Control Design. Pada penelitian ini kelas eksperimen diberi perlakuan model pembelajaran Value Clarification Technique sedangkan kelas kontrol menggunakan model pembelajaran konvensional.

Populasi yang diambil pada penelitian ini sebanyak 4 (empat) kelas, yaitu kelas XI IPA 1, XI IPA 2, XI IPA 3, dan XI IPA 4 yang berjumlah 136 siswa. Teknik pengambilan sampel dengan menggunakan Cluster Random Sampling. Teknik Cluster Random Sampling (teknik pengambilan sampel satu tahap) dipilih karena peneliti menganggap kemampuan semua subjek di dalam populasi sama atau homogen serta peneliti ingin memilih sampel secara random bukan individu tetapi kelompok-kelompok (kelas). Sampel yang digunakan pada penelitian ini 2 (dua) kelas, yaitu kelas XI IPA 2 sebagai kelas eksperimen dan kelas XI IPA 3 sebagai kelas kontrol dengan masing-masing kelas berjumlah 34 siswa.
Instrumen menggunakan observasi (pengamatan) dan kuisioner (angket). Peneliti menggunakan observasi terstruktur sebagai data penunjang untuk mendapatkan data tentang keberhasilan proses pembelajaran di kelas eksperimen dengan model pembelajaran value clarification technique. Peneliti menunjuk dua observer (pengamat) untuk mengamati proses pembelajaran dengan penerapan model value clarification technique di kelas. Observer (pengamat) mengisi lembar pedoman observasi yang telah disediakan oleh peneliti. Terdapat pedoman observasi berisi sebuah daftar jenis kegiatan yang akan timbul dan akan diamati, observer (pengamat) tinggal memberikan tanda contreng $(\sqrt{ })$ pada kolom tempat perilaku muncul.

Untuk mendapatkan data civic disposition (Y) siswa, peneliti menggunakan instrumen berupa angket. Jenis angket yang digunakan yaitu angket tertutup dengan menggunakan skala likert. Uji coba instrumen ini dilakukan di luar kelas kontrol dan kelas eksperimen, kemudian instrumen diuji validitas dan reliabilitas. Menurut Suharsimi Arikunto (2006: 168) "Validitas adalah suatu ukuran yang menunjukkan tingkat-tingkat kevalidan atau kesahihan suatu instrumen". Sementara itu, "Reliabilitas menunjuk pada satu pengertian bahwa sesuatu instrumen cukup dapat dipercaya untuk digunakan sebagai alat pengumpul data karena instrumen tersebut baik" (Suharsimi Arikunto, 2006: 178). Hasil 


\section{Tabel 1}

Rangkuman Uji Validitas Hasil Uji Coba atau Try Out

\begin{tabular}{|l|c|c|c|}
\hline \multicolumn{2}{|c|}{ Variabel } & Jumlah & \multicolumn{2}{|c|}{ Keputusan Uji Validitas } \\
\cline { 3 - 4 } & Item & Valid & Invalid \\
\hline Angket Civic Disposition Siswa Pada & 40 & 19 & 21 \\
Kompetensi Dasar Menghayati & & & \\
Berbagai Dampak dan Bentuk & & & \\
Ancaman terhadap Negara dalam & & & \\
Mempertahankan Bhinneka Tunggal & & & \\
Ika & & & \\
\hline
\end{tabular}

\section{Sumber : Diolah Peneliti}

Pada penelitian ini uji persyaratan yang digunakan adalah uji normalitas, uji independen, dan uji linieritas. Setelah melakukan uji persyaratan, langkah berikutnya adalah melakukan uji hipotesis. Uji hipotesis yang digunakan pada penelitian ini adalah uji t test.

\section{HASIL DAN PEMBAHASAN}

Penelitian mengenai penerapan model pembelajaran Value Clarification Technique terhadap Civic Disposition siswa kelas XI SMA Negeri 1 Teras Boyolali pada kompetensi dasar Menghayati Berbagai Dampak dan Bentuk Ancaman terhadap Negara dalam Mempertahankan Bhinneka Tunggal Ika telah dilaksanakan pada tanggal 25 April 2017 sampai dengan 16 Mei 2017. Penelitian dimulai dengan melakukan uji coba instrumen angket di kelas XI IPA 1 pada hari Rabu tanggal 26 April 2017 untuk mengetahui hasil uji validitas dan uji reliabilitas butirbutir pernyataan yang telah dibuat oleh penulis. Kemudian kegiatan pembelajaran dengan model pembelajaran Value Clarification Technique di kelas XI IPA 2 sebagai kelas eksperimen sebanyak satu kali pertemuan yaitu pada hari Selasa tanggal 09 Mei 2017 dengan waktu sekali pertemuan 2 x 45 menit. Kemudian melakukan kegiatan pembelajaran dengan model konvensional di kelas XI IPA 3 sebagai kelas kontrol sebanyak satu kali pertemuan yaitu pada hari Selasa tanggal 09 Mei 2017 dengan waktu sekali pertemuan 2 x 45 menit.

Model pembelajaran Value Clarification Technique merupakan variabel $\mathrm{X}$ (variabel bebas) dalam penelitian ini. Menurut Hall dalam Sutarjo Adisusilo (2013: 145) mengartikan teknik klarifikasi nilai sebagai berikut: "By value clarification we mean a methodology or process by which we help a person to discover values through behavior, feeings, ideas, and through important choiches he has made and is continually, in fact, acting upon in through his life". Yang artinya melalui klarifikasi nilai kita mengartikan bahwa metode atau proses 
yang mana akan membantu siswa memperlihatkan kebiasaan, ide, hal yang dianggap penting yang akan dijadikan pilihan secara berkelanjutan, yang pada kenyataannya dilakukan sepanjang hidupnya.

$$
\text { Sedangkan Wina Sanjaya }
$$
(2014: 283) mengartikan "VCT sebagai teknik pengajaran untuk membantu siswa dalam mencari dan menentukan suatu nilai yang dianggap baik dalam menghadapi suatu persoalan melalui proses menganalisis nilai yang sudah ada dan tertanam dalam diri siswa".

Berikut langkah-langkah atau indikator model pembelajaran Value Clarification Technique adalah sebagai berikut :

1) Guru menyajikan dilema moral;

2) Siswa mendalami dilema moral;

3) Siswa memilih nilai dan alasannya;

4) Siswa membentuk diskusi kelompok kecil;
5) Siswa melaksanakan diskusi pleno kelas;

6) Guru bersama siswa menutup diskusi kelas.

Instrumen yang digunakan untuk mengukur model pembelajaran Value Clarification Technique yaitu dengan lembar observasi. Berdasarkan penelitian yang dilaksanakan maka data yang diperolah dari hasil penelitian diolah.

Hasil penelitian ini adalah sebagai berikut :

1. Lembar Observasi

Observasi dilakukan oleh dua observer (pengamat) yaitu Dian Hayati Rahman sebagai pengamat 1 dan Dewi Sukmowati sebagai pengamat 2. Observer mengamati perilaku siswa secara keseluruhan pada saat diterapkannya model pembelajaran value clarification technique oleh praktikan selama proses pembelajaran berlangsung.

Tabel 2

Rangkuman Hasil Observasi Model Pembelajaran Value Clarification Technique Kelas XI IPA 2

\begin{tabular}{|c|c|}
\hline Pengamat & Skor \\
\hline Pengamat 1 & 90,21 \\
Pengamat 2 & 90,71 \\
\hline Jumlah & $\mathbf{1 8 0 , 9 2 : ~ 2 = 9 0 , 4 6}$ \\
\hline Kategori & Sangat Baik \\
\hline
\end{tabular}

Sumber : Diolah Peneliti

Hasil observasi (pengamatan) model pembelajaran value clarification technique yang telah dilakukan oleh dua observer (pengamat) diperoleh skor dari pengamat 1 yaitu $\mathbf{9 0 , 2 1}$ sedangkan pengamat 2 yaitu 90,71. Kemudian skor perolehan dari kedua observer (pengamat) tersebut di rata-rata menjadi satu sehingga diperoleh skor akhir yaitu 90,46 atau dapat dikatakan bahwa proses pembelajaran di kelas XI IPA 2 (kelas eksperimen) dengan model pembelajaran value clarification 
technique di kelas dalam kategori Sangat Baik.

Berdasarkan tabel rangkuman hasil observasi model pembelajaran value clarification technique di atas, dapat disimpulkan bahwa penerapan model pembelajaran value clarification technique yang dilakukan oleh praktikan di kelas eksperimen sudah terlaksana dengan sangat baik sesuai dengan langkah-langkah model pembelajaran value clarification technique. Hanya saja pada langkah terakhir yaitu guru bersama siswa menyimpulkan hasil diskusi perlu diperbaiki, mengingat pada langkah tersebut praktikan hanya menyimpulkan sendiri hasil diskusi tanpa melibatkan siswa.

Kriteria perolehan skor lembar observasi model pembelajaran value clarification technique dapat ditentukan dengan interpretasi sebagai berikut:

Tabel 3

Tabel 3 Kriteria perolehan skor lembar observasi model pembelajaran value clarification technique

\begin{tabular}{|c|c|}
\hline Persentase Pencapaian & Interpretasi \\
\hline $91-100$ & Sangat Baik \\
\hline $71-90$ & Baik \\
\hline $51-70$ & Cukup \\
\hline$<51$ & Kurang \\
\hline
\end{tabular}

Sumber : Depdiknas, $2010: 17$

memilih, menganalisis, memutuskan,

Model pembelajaran value clarification technique sesuai dengan teori belajar humanistik yang dikemukakan oleh Carl Rogers dalam Eveline Siregar dan Hartini Nara (2014: 37) "bahwa siswa yang belajar hendaknya tidak dipaksa, melainkan dibiarkan belajar bebas, siswa diharapkan dapat mengambil keputusan sendiri dan berani bertanggungjawab atas keputusan-keputusan yang diambilnya sendiri”.

Hal ini sejalan dengan Sutarjo Adisusilo (2013: 141) yang menyatakan bahwa:

Value Clarification Technique adalah pendekatan pendidikan nilai dimana peserta didik dilatih untuk menemukan, mengambil sikap sendiri nilai-nilai hidup yang akan diperjuangkan. Peserta didik dibantu menjernihkan, memperjelas, mengklarifikasi nilai-nilai hidupnya, lewat values problem solving, diskusi, dialog dan presentasi. Misalnya peserta didik dibantu menyadari nilai-nilai demokrasi yang perlu diterapkan dalam kehidupan sehari-hari baik di lingkungan keluarga, sekolah dan masyarakat lewat pembahasan kasus-kasus hidup yang sangat erat dengan konflik nilai dan moral.

Penerapan model pembelajaran value clarificaion technique mendorong siswa kelas XI IPA 2 untuk mampu mengembangkan diri dan mengaktulisasikan diri dengan cara aktif mengemukakan pemikiran, 
gagasan dan pendapat dalam menanggapi suatu masalah dalam forum diskusi pada kompetensi dasar menghayati berbagai dampak dan bentuk ancaman terhadap negara dalam mempertahankan Bhinneka Tunggal Ika. Model pembelajaran value clarification technique juga mampu membantu siswa mengembangkan kemampuannya dalam berempati dengan orang lain khususnya apabila ada siswa lain yang berbeda pendapat dengannya. Siswa juga mampu mengembangkan kemampuannya dalam menerima dan menolak pendapat suatu kelompok serta mengambil keputusan atau sikap yang diperlukan dalam menghadapi contoh kasus berkaitan dengan ancaman terhadap negara dalam mempertahankan Bhinneka Tunggal Ika.

value $\begin{array}{cc}\text { Penerapan model pembelajaran } \\ \text { clarification technique }\end{array}$ berpengaruh terhadap civic disposition siswa kelas XI IPA 2 di SMA Negeri 1 Teras Boyolali ditunjukkan dari hasil penelitian melalui penyebaran angket civic disposition siswa pada kompetensi dasar menghayati berbagai dampak dan bentuk ancaman terhadap negara dalam mempertahankan Bhinneka Tunggal Ika kepada siswa kelas XI IPA 2 sebagai kelas eksperimen. Pencapaian indikator - indikator civic disposition dapat terpenuhi setelah diterapkannya model pembelajaran value clarification technique antara lain:

1. Siswa bersedia menerima perbedaan kelompok etnis dan ras dengan persentase tertinggi mencapai $87 \%$ pada butir pernyataan kesediaan bekerjasama dengan teman yang berbeda ras dan etnis.

2. Siswa bersedia menghargai teman sekelasnya yang berbeda agama dengan persentase tertinggi mencapai $90 \%$ pada butir pernyataan kesediaan memberi kesempatan teman yang berbeda agama untuk beribadah.

3. Siswa memiliki kesadaran akan keanekaragaman budaya Indonesia dengan persentase tertinggi mencapai $86 \%$ pada butir pernyataan kesediaan menghargai pandangan teman terhadap suatu hal.

4. Siswa bersedia menghargai teman sekelasnya yang berbeda gender dengan persentase tertinggi mencapai $90 \%$ pada butir pernyataan perlunya perempuan memperoleh pendidikan yang tinggi.

5. Siswa bersedia membangun sikap toleransi dengan teman sekelasnya dengan persentase tertinggi mencapai $85 \%$ pada butir pernyataan kesediaan mendengarkan pendapat teman.

Guru memberikan contoh kasus dilema moral. Kemudian tercipta suasana yang nyaman dan tidak tegang sehingga siswa berani untuk berbicara dan bertanya kepada guru maupun teman yang lain. Semua pendapat siswa ditampung dan diapresiasi oleh guru sehingga siswa merasa senang dan memotivasi siswa untuk mengemukakan gagasan kembali. Penggunaan contoh kasus tersebut 
membuat siswa mampu mendalami dan mengutarakan pendapatnya terhadap kasus tersebut. Siswa juga dihadapkan pada situasi dilematis berkaitan dengan sikap yang perlu mereka ambil apabila mereka dihadapkan pada situasi sebagaimana kasus yang telah dipaparkan oleh guru. Setelah siswa megutarakan pendapatnya dalam forum diskusi, siswa mampu merencanakan dan menentukan keputusan berupa mengambil nilai-nilai yang terkandung dalam materi pembelajaran dan membuat sikap siswa (civic disposition) lebih terlihat serta berkembang dengan baik.

Berikut hasil angket civic disposition siswa kelas XI SMA Negeri 1 Teras Boyolali:
1. Data Angket Civic Disposition Kelas XI IPA 2 (Kelas Eksperimen)

Dari data angket civic disposition (Y) siswa pada kompetensi dasar menghayati berbagai dampak dan bentuk ancaman terhadap negara dalam mempertahankan Bhinneka Tunggal Ika kelas XI IPA 2 sebagai kelas eksperimen dengan sampel sebanyak 34 siswa diperoleh skor tertinggi 72 dan skor terendah 54. Dengan ratarata (X) 65,38, Simpangan Baku (S) sebesar 5,003, Median 66,5, Modus 69 dan 72. Sedangkan Rentang (R) adalah 18, Banyaknya kelas (P) 6,054 dibulatkan menjadi 7 dan panjang kelas 2,571 dibulatkan menjadi 3.

Tabel 4

Distribusi Frekuensi Data Civic Disposition Siswa Kelas XI IPA 2 (Kelas Eksperimen) di SMA Negeri 1 Teras Boyolali Tahun Ajaran 2016/2017

\begin{tabular}{|c|c|c|c|c|}
\hline Kelas & Interval & Nilai Tengah & F & FK \\
\hline 1 & $54-56$ & 55 & 1 & 1 \\
\hline 2 & $57-59$ & 58 & 4 & 5 \\
\hline 3 & $60-62$ & 61 & 6 & 11 \\
\hline 4 & $63-65$ & 64 & 5 & 16 \\
\hline 5 & $66-68$ & 67 & 6 & 22 \\
\hline 6 & $69-71$ & 70 & 8 & 30 \\
\hline 7 & $72-74$ & 73 & 4 & 34 \\
\hline
\end{tabular}

Sumber : Daftar Nilai Tes PKn Kondisi Awal, Siklus I dan II diolah

2. Data Angket Civic Disposition Kelas XI IPA 3 (Kelas Kontrol)

Dari data angket civic disposition (Y) siswa pada kompetensi dasar menghayati berbagai dampak dan bentuk ancaman terhadap negara dalam mempertahankan Bhinneka Tunggal Ika kelas XI IPA 3 sebagai kelas kontrol dengan sampel sebanyak 34 siswa diperoleh skor tertinggi 71 dan skor terendah 52. Dengan rata-rata $(\mathrm{X}) \mathbf{6 1 , 5}$, Simpangan Baku (S) sebesar 5,050, Median 61,32, Modus 56,61,62. Sedangkan Rentang (R) adalah 19, banyaknya kelas (P) 6,054 dibulatkan menjadi 7 dan panjang kelas $\mathbf{2 , 7 1 4}$ dibulatkan menjadi 3. 
PKn Progresif, Vol. 13 No. 2 Desember 2018

Tabel 5

Distribusi Frekuensi Data Civic Disposition Siswa Kelas XI IPA 3 (Kelas Kontrol) di SMA Negeri 1 Teras Boyolali Tahun Ajaran 2016 / 2017

\begin{tabular}{|c|c|c|c|c|}
\hline Kelas & Interval & Nilai Tengah & $\mathbf{F}$ & FK \\
\hline 1 & $52-54$ & 53 & 3 & 3 \\
\hline 2 & $55-57$ & 56 & 7 & 10 \\
\hline 3 & $58-60$ & 59 & 4 & 14 \\
\hline 4 & $61-63$ & 62 & 8 & 22 \\
\hline 5 & $64-66$ & 65 & 6 & 28 \\
\hline 6 & $67-69$ & 68 & 4 & 32 \\
\hline 7 & $70-72$ & 71 & 2 & 34 \\
\hline
\end{tabular}

Selanjutnya dilakukan uji untuk mengetahui apakah data yang prasyarat, uji persyaratan yang digunakan diambil dari distribusi normal atau tidak. pada penelitian ini adalah uji normalitas Uji normalitas ini menggunakan uji Chi dan uji homogenitas. Berdasarkan hasil Kuadrat. Hasil uji normalitas dengan penelitian diperoleh data sebagai berikut : taraf signifikansi 5\% pada masing1. Uji Normalitas masing kelas.

Tabel 6

Hasil Uji Normalitas Angket Civic Disposition Siswa Kelas Eksperimen dan

Kelas Kontrol.

\begin{tabular}{|c|c|c|}
\hline Kelas & Harga $\boldsymbol{\chi}_{\text {hitung }}^{2}$ & Harga $\chi_{\text {tabel }}^{2}$ \\
\hline Eksperimen & 3,484 & 12,59 \\
\hline Kontrol & 12,29 & 12,59 \\
\hline
\end{tabular}


Sampel berasal dari populasi yang berdistribusi normal jika $\chi_{\text {hitung }}^{2}<$ $\chi_{\text {tabel }}^{2}$. Harga $\chi_{\text {hitung pada masing- }}^{2}$ masing variabel dan kelas di atas lebih kecil dari $\chi_{\text {tabel sehingga dapat }}^{2}$ disimpulkan bahwa sampel dalam penelitian berasal dari populasi yang berdistribusi normal.

\section{Uji Homogenitas}

Pengujian homogenitas dimaksudkan untuk mengetahui obyek yang akan diteliti memiliki varian yang sama atau tidak. Berdasarkan perhitungan uji homogenitas antara data civic disposition kelas eksperimen dengan data civic disposition kelas kontrol diperoleh $\chi^{2}$ hitung sebesar 0,152 dan telah dikonsultasikan dengan $\chi^{2}$ tabel $(\mathrm{k}-1=2-1=1)$ pada taraf signifikansi $5 \%$ diperoleh sebesar 3,84 sehingga dapat diketahui bahwa $\chi^{2}$ hitung $<\chi^{2}$ tabel yaitu $0,152<3,84$. Maka dapat disimpulkan varian-varian sampel adalah homogen.

Setelah melakukan uji prasyarat analisis, langkah selanjutnya adalah melakukan uji hipotesis. Uji hipotesis dilakukan setelah uji prasyarat analisis terpenuhi. Untuk mengetahui uji hipotesis analisis data yang digunakan adalah uji-T.

Berdasarkan penjelasan perhitungan data penelitian di atas diperoleh skor rata-rata kelas eksperimen sebesar 65,38 dan apabila dikonversikan dalam skala 0-100 yaitu 86,03 sedangkan skor rata-rata kelas kontrol sebesar 61,38 dan apabila dikonversikan dalam skala 0-100 yaitu 80,76. Kemudian dilakukan uji persyaratan analisis meliputi uji normalitas dan uji homogenitas. Setelah dilakukan uji persyaratan analisis kemudian dilakukan pengujian hipotesis.

Pengujian hipotesis data dilakukan dengan teknik analisis data uji-t dua sampel, digunakan untuk mengetahui ada tidaknya perbedaan civic disposition siswa antara kelas eksperimen dan kelas kontrol. Sehingga dari hasil tersebut dapat disimpulkan apakah terdapat pengaruh model pembelajaran value clarification technique terhadap civic disposition siswa pada kompetensi dasar menghayati berbagai dampak dan bentuk ancaman terhadap negara dalam mempertahankan Bhinneka Tunggal Ika kelas XI di SMA Negeri 1 Teras Boyolali tahun ajaran 2016/2017.

Berdasarkan hasil perhitungan diperoleh $t_{\text {hitung }}$ sebesar 13,560. Hasil tersebut dikonsultasikan dengan tabel $\mathrm{t}$ dengan taraf signifikansi $5 \%$ dan $\mathrm{db}=$ $n_{1}+n_{2}-2(34+34-2=66)$ sehingga diperoleh $\mathrm{t}$ tabel sebesar 1,997 (interpolasi atau prinsip perbandingan senilai). Maka $t$ hitung $(13,560)>t_{\text {tabel }}$ $(1,997)$ dan skor rata-rata kelas eksperimen $(86,03)$ lebih tinggi dibandingkan skor rata-rata kelas kontrol (80,76), menunjukkan ada perbedaan yang signifikan civic disposition siswa antara kelas eksperimen dan kelas kontrol.

Maka dapat disimpulkan bahwa terdapat pengaruh model pembelajaran value clarification technique terhadap civic disposition siswa pada kompetensi 
dasar menghayati berbagai dampak dan bentuk ancaman terhadap negara dalam mempertahankan Bhinneka Tunggal Ika.

Hal tersebut didukung dengan pernyataan informan siswa kelas XI IPA 2 yang menyatakan bahwa :

"Menurut saya model pembelajaran yang ibu terapkan itu lebih friendly dan menyenangkan, tidak terlalu tegang. Sehingga siswa bisa mengutarakan yang menjadi pendapat mereka tanpa rasa takut dan segan, karena tanggapan yang diberikan ibu mengenai pendapat yang disampaikan siswa juga tidak langsung menyalahkan atau membenarkan melainkan ibu memberi masukan dan menambah pengetahuan kami. Jika dibandingkan dengan guru lain yang mengajar, mereka cenderung memberi tahu saja tanpa memberikan peluang bagi siswa untuk mengutarakan pendapat mereka, disini saya khususkan ke pelajaran PPKn. Saya juga bisa mengambil nilai atau pelajaran dari materi yang ibu sampaikan. Walaupun terkadang saya sudah tahu maksudnya kemudian bingung jika ada pendapat dari teman yang lain karena tidak sesuai dengan apa yang saya tangkap". (Wawancara pada hari Kamis, 03 Agustus 2017).

\section{KESIMPULAN DAN SARAN}

\section{A. Kesimpulan}

Berdasarkan hasil penelitian dan analisis data dapat disimpulkan bahwa penerapan model pembelajaran Value Clarification Technique pada kelas XI IPA 2 SMA Negeri 1 Teras Boyolali Tahun Ajaran 2016/2017 berpengaruh terhadap Civic Disposition siswa pada kompetensi dasar menghayati berbagai dampak dan bentuk ancaman terhadap negara dalam mempertahankan Bhinneka Tunggal Ika.

Kesimpulan tersebut dibuktikan dengan data hasil penelitian pada kelas XI IPA 2 sebagai kelas eksperimen dan Kelas XI IPA 3 sebagai kelas kontrol di SMA Negeri 1 Teras Boyolali Tahun Ajaran 2016/2017. Hasil penelitian menunjukkan bahwa skor rata-rata kelas eksperimen lebih tinggi dengan rata-rata hitung sebesar 65,38 dan apabila dikonversikan dalam skala 0100 yaitu 86,03 sedangkan skor ratarata kelas kontrol sebesar 61,38 dan apabila dikonversikan dalam skala 0100 yaitu 80,76. Kedua sampel yang diambil masing-masing berjumlah 34 siswa dengan varians data homogen. Kemudian pengujian hipotesis dilakukan dengan uji-t dua sampel dengan taraf signifikansi 5\% diperoleh $\mathrm{t}$ hitung $(13,560)>\mathrm{t}$ tabel $(1,997)$ menunjukkan adanya perbedaan civic disposition siswa antara kelas eksperimen dengan kelas kontrol $\left(\mathrm{H}_{0}\right.$ ditolak).

\section{B. Saran}

Selanjutnya saran-saran tersebut diberikan kepada :

\section{Siswa}

Melalui kegiatan memilih prioritas nilai, siswa hendaknya berusaha untuk mengidentifikasi nilai-nilai mereka sendiri serta mampu mengkomunikasikan secara terbuka dan jujur dengan orang lain, berkaitan dengan nilai-nilai yang diyakini.

\section{Guru}

Guru PPKn hendaknya memperhatikan tujuan pembelajaran PPKn baik pada 
ranah kognitif, afektif, maupun psikomotorik. Salah satu alternatifnya adalah dengan menerapkan model pembelajaran value clarification technique karena melalui model pembelajaran value clarification technique tujuan pembelajaran PPKn pada ketiga ranah tersebut dapat tercapai sekaligus.

\section{Kepala Sekolah}

Hendaknya sekolah lebih mendorong guru agar lebih inovatif, mengadakan pelatihan kepada guru agar lebih berani bereksperimen khususnya terkait penerapan model pembelajaran di kelas demi kemajuan proses pembelajaran, serta memberikan pengarahan dan pengawasan kepada siswa agar disamping memiliki pengetahuan yang bagus juga harus memiliki keterampilan dan sikap yang baik sebagai wujud menjadi warganegara yang baik (Good Citizen).

\section{Peneliti lain}

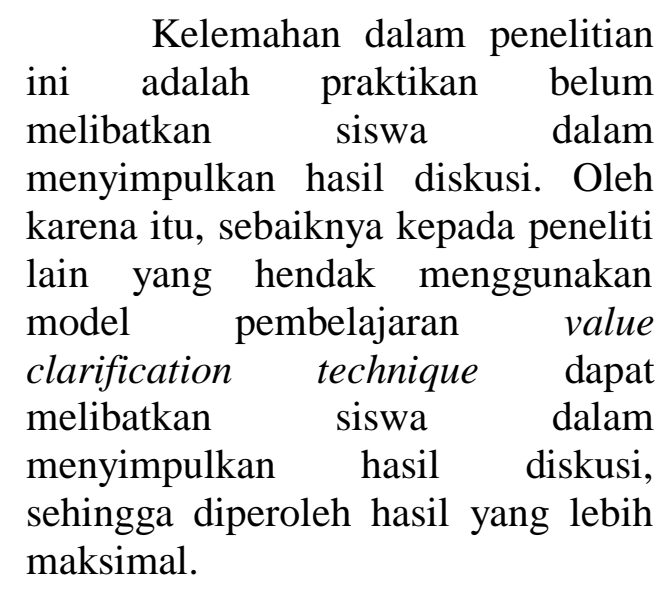

\section{DAFTAR PUSTAKA}

Prabowo, Wawan H. (2017). Asal Muasal Penelitian Kemendikbud dan Temuan Sikap Intoleransi di Sekolah, Kompas, paragraf.13

Siregar, Eveline \& Hartini Nara. (2014). Teori Belajar dan Pembelajaran. Bogor: Ghalia Indonesia

Suharsimi Arikunto. (2006). Prosedur Penelitian Suatu Tindakan Praktik. Jakarta: Rineka Cipta

Sutarjo Adisusilo. (2013). Pembelajaran Nilai-Karakter : Konstruktivisme dan VCT Sebagai Inovasi Pendekatan Pembelajaran Afektif. Jakarta : PT Raja Grafindo Persada Jakarta

Wina Sanjaya. (2014). Strategi Pembelajaran Berorientasi Standar Proses Pendidikan. Jakarta: Kencana Prenadamedia Group 